The Catholic University of America, Columbus School of Law

CUA Law Scholarship Repository

2015

Reform in 1215: Magna Carta and the Fourth Lateran Council

Kenneth Pennington

The Catholic University of America, Columbus School of Law

Follow this and additional works at: https://scholarship.law.edu/scholar

Part of the Legal History Commons, and the Medieval History Commons

Recommended Citation

Kenneth Pennington, Reform in 1215: Magna Carta and the Fourth Lateran Council, 32 BULL. MEDIEVAL CANON L. 97 (2015).

This Article is brought to you for free and open access by the Faculty Scholarship at CUA Law Scholarship Repository. It has been accepted for inclusion in Scholarly Articles and Other Contributions by an authorized administrator of CUA Law Scholarship Repository. For more information, please contact edinger@law.edu. 


\title{
Reform in 1215: Magna Carta and the Fourth Lateran Council
}

\author{
Ken Pennington
}

800 years ago, in June and November of 1215, two great events took place that have shaped our imaginations about law, reform, and constitutional and individual rights to the present day: The meeting of King John of England with the magnates of his realm on the fields of Runnymede and the great church council in which the prelates of the Church gathered around Pope Innocent III in the papal basilica San Giovanni in Laterano were focused on the the great issues of the time. Both meeting produced documents that have been interpreted by scholars, read by students, and debated by everyone.

By 1215 King John had lost almost all of his northern continental possessions. The core of the Angevin empire, Normandy, was lost. Anglo-French barons who still held lands in Normandy owed their primary allegiance to King Phillip Augustus, not to King John. The barons and churchmen who remained under his sovereignty chaffed under his rule. It is clear from the document that the barons forced John to sign when they met with John on Runnymede in 15 July 2015, they intended to impose reform on the king. We might sum up their objectives as being the administration of justice and defending their customary rights in what remained of the John's kingdom.

Magna Carta was a major event in King John's reign. Because the archbishop of Canterbury, Stephen Langton, played such a significant role in the affair that took place on Runnymede, scholars have wondered about the connections canon law and its jurisprudence embedded in the Ius commune might have had in the minds of those who drafted the document. ${ }^{1}$

\footnotetext{
${ }^{1}$ For a recent continental view of Stephen Langton's relationship to the barons and to Magna Carta see Daniel Baumann, Stephen Langton: Erzbischof von Caterbury im England der Magna Carta (1207-1228) (Studies in Medieval and Reformation Traditions 144; Leiden-Boston 2009) 159-189; John W. Baldwin, 'Master Stephen Langton, Future Archbishop of Canterbury: The
} 
A larger question is the relationship of the Ius commune to English common law in the early stages of its development. Charles Donahue wanted to have a word to illustrate the relationship. He chose 'influence'. Twenty-five years ago he wrote: ${ }^{2}$

We need a word to tie the ius commune to the common law of England. The standard word is 'influence', and the standard meaning of the word is direct borrowing of rules and sometimes broader principles.

That may seem as if it would be a statement that would evoke little controversy in the world of legal history. Nevertheless, it has. Scholarly attempts to explore the 'influences' that the jurisprudence of the Ius commune might have had on English common law and Magna Carta have been met with criticism, some of it rather pointed. ${ }^{3}$ In this essay I will examine possible 'influences' that the Ius commune may have had on Magna Carta and the relationship and possible connections between the two most significant reform assemblies in the early thirteenth century: the king, prelates, and barons who gathered at Runnymede and the pope, cardinals, bishops, abbots, and clergy who congregated in San Giovanni in Laterano.

I begin at a strange place, neither in England nor in Rome, but in Rouen, France. A manuscript resides there that dates to the early thirteenth century and belonged to the lepers' hospital of Saint Gilles in the Norman city of Pont-Audemer. It contains documents related to the hospital and its founding but also contains the canons of the Fourth Lateran Council and cheek by jowl a French translation of Magna Carta. ${ }^{4}$ James Clarke

Paris Schools and Magna Carta', EHR 123 (2008) 811-846, especially 834835.

${ }^{2}$ Charles Donahue, Jr. 'I $u$ s commune, Canon Law, and the Common Law in England', Tulane Law Review 66 (1991-1992) 1745-1780 at 1747.

${ }^{3}$ Richard H. Helmholz, 'Magna Carta and the ius commune', The University of Chicago Law Review 66 (1999) 297-370.

${ }^{4}$ Simone C. Mesmin (later MacDougall), The Leper Hospital of Saint Gilles de Pont-Audemer : An Edition of its Cartulary and an Examination of the Problem of Leprosy in the Twelfth and Early Thirteenth Centuries (Ph. D. dissertation, 2 volumes, University of Reading 1978) has given a detailed 
Holt had examined the cartulary and published an edition of the French text in $1974 . .^{5}$ Holt tried to explain why Magna Carta was translated into French and why a copy of it found its way into a cartulary of a small foundation in Normandy. He noted that the manuscript copy of Magna Carta had the text of a writ addressed to the sheriff of Hampshire appended to it. ${ }^{6}$ The writ instructed the sheriff to compel people to obey the twenty five barons who had been designated by the charter to enforce its provisions. ${ }^{7}$ Bishop of Winchester, Peter des Roches was appointed the sheriff of Hamsphire in $1216 .^{8}$

Bishop Peter had an unusually interesting career. Born in Touraine he rose from being the archdeacon in the diocese of Poitiers to become Lord Chamberlain under Richard the Lionheart, then was elected to the see of Winchester in 1205. King John chose him to be chief justice of the realm in $1213 .{ }^{9}$ He was a stubborn supporter of the king and fiercely loyal to him. In the Spring or Summer of 1215 Innocent sent a letter to Bishop Peter in which the pope told the bishop that he should prevent his court from hearing suits' belonging in secular courts. He also informed him that he would promulgate rules at the

description of the cartulary and translated the documents. She has also edited other related documents from the archives.

5 James C. Holt, 'A Vernacular-French Text of Magna Carta, 1215', The English Historical Review 89 (1974) 346-364. The text had been printed before in early modern editions. French translations of three coronation charters of Henry I, Stephen, and Henry II in British Library, Harley 458, fol. $4 \mathrm{r}-4 \mathrm{v}$ deserve scholarly scrutiny (my thanks to Jennifer Jahner for this information); see images at

http://www.earlyenglishlaws.ac.uk/laws/manuscripts/hl/?nb=3191\&tp=s

and the rather unsatisfactory images in James C. Holt, Magna Carta $\left(3^{\text {rd }}\right.$ ed. Cambridge 2015) between 234-235.

6 Ibid. 464: 'Johan par la grace de Deu reis d'Engleterre al viconte de Suthantesire'.

${ }^{7}$ Ibid. 348.

${ }^{8}$ Nicholas Vincent, Peter des Roches: An Alien in English Politics, 1205-1238 (Cambridge Studies in Medieval Life and Thought, $4^{\text {th }}$ series, 31; Cambridge 1996).

${ }^{9}$ Vincent, Peter des Roches 89-113. 
upcoming council about the issue. ${ }^{10}$ Innocent also mentioned that he asked John to send proctors to the council to defend his rights.

Holt argued that the translation of Magna Carta and the writ delivered to Odiham must have been drafted in Hampshire and that the translation was made for publication there. ${ }^{11}$ Odiham was a secure royal fortress, and its ruins are still known today as 'King John's castle'. He spent time there before and after Runnymede. ${ }^{12}$ However, John met Stephen Langton at Winchester on 20-21 July 1215. ${ }^{13}$ The Latin version of the writ was that sent to all the sheriffs of England on the $27^{\text {th }}$ June from Winchester. ${ }^{14}$ The last line of the French writ states that John witnessed the writ at Odiham on 27 June 1215. Odiham is ca. 25 miles from Winchester. John could have been in both places on the same day. Holt does not consider the possibility that a Latin and French version of the writ might have been sent at the same time to the sheriffs of the realm and that the French translation was a product of chancery scribes in Winchester. ${ }^{15}$

10 Paris, BNF lat. 11867, fol. 37vb-38ra.The Latin text is printed and translated in Selected Letters of Pope Innocent III concerning England (11981216), edd. Christopher R. Cheney and W.H. Semple (Nelson's Medieval Texts; London-Edinburgh-Paris-Melbourne-Toronto-New York 1953) 205206, which was based on the earlier edition of Karl Hampe, 'Aus verlorenen Registerbänden der Päpste Innocenz III. und Innocenz IV.' MIÖG 23 (1902) 545-67 at 556-557.

${ }^{11}$ Holt, 'Vernacular-French Text' 348.

12 J.C. Holt, Magna Carta (Cambridge: Cambridge University Press, 1965) 154-155 and ( $3^{\text {rd }}$ ed.) 214-215.

${ }^{13}$ Baldwin, 'Master Stephen Langton' 827.

${ }^{14}$ Ibid. 347 for the Latin text.

15 In the new and augmented edition of Holt's Magna Carta edited and prepared by George Garnett and John Hudson ( $3^{\text {rd }}$ ed. Cambridge 2015), appendix 7 deals with the French translations. It does not discuss the possible place where the translation was made or its transmission. The different scripts in the French translations of the coronation oaths of Henry I, Stephen, and Henry II found in British Library, Harley 458, fol. 4r-4v are dated to the same period. I am not sure that is correct. An analysis of the French translation's language might resolve some of the problems. For the importance of Henry I's coronation oath, see Baldwin, 'Master Stephen Langton' 828. 
A larger question is how many copies of Magna Carta and its French translations were sent out. We know that Master Elias of Dereham, who was a first-rate administrator, played a significant role in the distribution of the Latin text of Magna Carta. Vincent has described how he may have accompanied Archbishop Stephen Langton to Runnymede and then was given the task of distributing four copies of Magna Carta. One month later Elias was given six more copies of the text to deliver. ${ }^{16}$ That much we know. There were probably more people involved in the Charter's distribution. ${ }^{17}$ The translation in Rouen must have been done and circulated about the same time. Thirteen bishops and twenty abbots witnessed the Charter. In their European-wide, ecclesiastical realm it was standard practice that significant legislation was distributed widely. A comparison to the legislation of the Fourth Lateran Council is instructive. Even though the canons were almost immediately incorporated into canonical collections that were taught in the schools and used in the courts, the canons circulated widely as separate texts. There are twenty manuscripts in all. ${ }^{18}$ Although we cannot know how the circulation of the canons was organized, we can tell from the manuscript evidence that they were all produced by professional scribes in scriptoria. In some cases they were produced with great care and elegantly decorated. ${ }^{19}$ One might presume that the bishops at Runnymede would have wanted the document that they witnessed to be distributed similarly. Their chanceries had the means to do so.

16 Nicholas Vincent, 'Master Elias of Dereham (d.1245): A Reassessment', The Church and Learning in later Medieval Society: Essays in Honour of R.B. Dobson, edd. Caroline M. Barron and Jenny Stratford (Harlaxton Medieval Studies11; Donnington 2002) 128-159 at 141.

17 As Vincent as observed in the Times Literary Supplement February 20, 2015 there may be charters yet to be discovered whose circulation has left no trace in the records. He also points out that later charters were circulated systematically. My thanks to Richard Helmholz for this citation.

18 Antonio García y García, Constitutiones Concilii quarti Lateranensis una cum Commentariis glossatorum (MIC Series A 2; Città del Vaticano 1981) 21-31; seven were English.

${ }^{19}$ E.g. Lisbon, BN 173 (Alcobaça CCCIV), fol. 1ra-9vb; García, Constitutiones 25-26. 
Peter des Roches surrounded himself with Frenchmen in his episcopal household. ${ }^{20} \mathrm{He}$ had the bureaucracy in Winchester with the means to produce and send out these documents. ${ }^{21}$ Even more significantly, Winchester had the most talented scribes and professional scriptoria in England. The Winchester Bible that was produced in the second half of the twelfth century and the Cotton Psalter now in the British Library bear witness to a scriptorium of great sophistication even before Peter des Roches' arrival. ${ }^{22}$ Winchester also had a tradition of translating Latin texts into French. The Cotton Psalter is a remarkable example of the talent of translators in Winchester (presumably) before the translator of Magna Carta. ${ }^{23}$ The Psalter's alternating columns of Latin and an excellent French translation is evidence of flourishing tradition. ${ }^{24}$ A study of its French in comparison to the French Magna Carta might prove illuminating. ${ }^{25}$

If the French translation of Magna Carta and the writ is a sole survivor of many that were sent out, then undoubtedly the Winchester chancery would have followed the practice of the papal chancery. Each individual charter would have been

\footnotetext{
${ }^{20}$ Vincent, Peter des Roches 32-41.

${ }^{21}$ For translations in England of texts from the vernacular into Latin and Latin into the vernacular, see Bruce R. O'Brien, Reversing Babel: Translation among the English during an Age of Conquests, c. 800 to c. 1200 (Newark 2011).

22 Claire Donovan, The Winchester Bible (Winchester 1993), based on the meticulous and brilliant sensitivity to style of Walter Oakeshott, The Artists of the Winchester Bible (London 1945) 3.

${ }^{23}$ London BL Cotton Nero C.IV. The entire manuscript can be viewed in great detail at:

http://www.bl.uk/manuscripts/Viewer.aspx?ref=cotton ms nero c iv fs $001 \mathrm{r}$

${ }^{24}$ Some art historians are no longer certain that the psalter can be connected to Winchester; see Frances Carey, The Apocalypse and the Shape of things to Come (Toronto 1999) 70, with bibliography.

${ }^{25}$ Ursula Nilgen has examined the Winchester Psalter; see her 'Psalter für Gelehrte und Ungelehrte im hohen Mittelalter', The Illuminated Psalter: Studies in the Content, Purpose and Placement of its Images, ed. Frank Olaf Büttner (Turnhout 2004) 239-247 and 510-513, as well as her other works. She has summarized her studies in LMA 9 (2002) 227-228, with bibliography.
} 
individually addressed. ${ }^{26}$ In any case, the scribe misspelled Odiham in the last line of the writ, which was corrected in the Rouen manuscript. The scribal error of misspelling Odiham would be good evidence the writ was not drafted there. A home town scribe would not have made such an elementary mistake. A further consideration in thinking about the writs' origins might be that Odiham would have been an unlikely place to have found a highly skilled translator. The household of Peter des Roches in Winchester with its entourage of continental clerics would have had translators who were up to the task. The reader should be warned, however, that I may be pressing the evidence further than is warranted.

Holt recognized the translator's skill translating Latin into French, but the translation is far from 'mechanical'. ${ }^{27}$ I would note that he had quite remarkable skill translating Latin legal terms into French. ${ }^{28}$ The three chapters dealing with legal procedure are very adroitly rendered, even better in some small ways than the Latin version. Chapter 38 states: ${ }^{29}$

$<38>$ Nuls bailliz ne mette des ci en avant alcun a lei par sa simple parole, fors par bons tesmoinz amenez a ice (Nullus ballivus ponat decetero aliquem ad legem simplici loquela sua, sine testibus fidelibus ad hoc inductis). From this time forward no bailiff shall bring anyone to court on just his authority alone, unless good witnesses provide evidence.

Richard Helmholz has noted that the Latin text makes use of the language of the Ius commune with the word 'testis' rather than 'sectatores' that would be more fitting for English common law. 30 The Latin text employs an unusual adjective: 'testibus fidelibus'. No text of the Ius commune called for 'faithful', or

\footnotetext{
${ }^{26}$ Holt, 'French Vernacular Magna Carta' 348: 'all the evidence suggests that the translation was done to facilitate the publication of the Charter in Hampshire . . . the translation must have been made from the original letters'. ${ }^{27}$ Holt, 'French Vernacular Magna Carta' 350.

${ }^{28}$ We might also compare the translation to the other English translations of legal texts and a legal glossary, see O'Brien, Reversing Babel 125 and 164.

${ }^{29}$ My translations of chapters 38, 39, and 40 are taken from Holt, Magna Carta 327 ( $3^{\text {rd }}$ ed.) 389.

${ }^{30}$ Richard H. Helmholz, 'Magna carta and the ius commune', The University of Chicago Law Review 66 (1999) 297-371 at 337.
} 
the more usual meaning 'Christian', witnesses. At the Fourth Lateran Council that was held in November of 1215, canon eight dealt with exactly the same issue: who could convince a magistrate and give him the authority to summon a defendant to court without an accuser? The conciliar canon's answer was that repeated information from prudent and honest persons (providus et honestus) would give magistrates jurisdiction. ${ }^{31}$ Writing shortly after 1215 Tancred of Bologna noted that if the witnesses who brought information to the attention of the magistrate were to be 'good and eminent/important' (bonus et gravis). ${ }^{32}$ 'Boni testes' or 'idonei testes' became the standard language used by the jurists to describe the qualities of witnesses in legal proceedings of all types. ${ }^{33}$ In any case the translator understood that the Latin 'fidelis' was misleading and equivocal. It could mean a Christian or simply a faithful person. In either case it was not a legal term and did not define the proper credentials that a witness should have. He translated 'fidelis' as 'bon'. The same term used by the Ius commune.

Undoubtedly the most famous chapter in the charter is 39. It is of great consequence historically because formidable structures of legal due process and constitutional government have been built upon its words over the centuries, whether such buildings had solidity or not.

$<39>$ Nuls frans hom ne sera pris, ne emprisonez, ne dessaisiz, ne ullagiez, ne eissilliez, ne destruiz en aucune maniere, ne sor lui n'irons ne n'enveierons, fors par leal jugement de ses pers, o par la lei de la terre (Nullus liber homo capiatur vel imprisonetur aut disseisiatur aut utlagetur aut exuletur aut aliquot modo destruatur, nec

${ }^{31}$ Chapter 4 of Magna Carta has this language 'duobus legalibus et discretis hominibus', which the French translator rendered 'a deus leals prodes homes'. 'Prod' means 'prudent'. In this case 'discretus' conforms more closely to the language of the jurists in the Ius commune than 'prod (prudentis)'. 'Prudentis' was most often was used to describe a judge not a witness.

32 153-154 'Verumtamen fama precedere debet inquisitionem, non semel, set sepe, et apud bonos et graves procedure debet; aliter non debet fieri inquisitio, sicut expresse habetur, extra de accusat. Qualiter et quando (X 5.1.3)', collated with Paris, BNF lat. 4366B, fol. 29vb.

${ }^{33}$ E.g. Bernardus Parmensis, Glossa ordinaria to X 2.19.5 s.v. testium. Many more examples could be given. 
super eum ibimus, nec super eum mittemus, nisi per legale iudicium parium suorum vel per legem terre).

No free man shall be taken or imprisoned or desseised or outlawed or exiled or in any way ruined, nor will we move nor send against him, except by the lawful judgment of his peers or by the law of the land.

It also has the most intriguing phrase of the whole document, 'legale iudicium', normally translated 'legal judgment', which is accurate and most likely correct. What makes the phrase intriguing is the question, what is not a legal 'iudicium?' A 'iudicium' was the Latin term, taken from Roman law and incorporated into canon law, for a trial or (more rarely) a courtroom. A 'legale iudicium' is a tautology; every 'iudicium' is 'legale'. Although a legal judgment makes sense in modern English, a non-legal 'iudicium' is a concept that does not exist in the Ius commune. A jurist of the Ius commune would have smiled indulgently at the formulation.

The phrase had roots in the continental 'iura propria'. As far as I can tell, for a short time during the Carolingian period the term 'legale iudicium' was used to describe certain legal decisions. One of the most famous was the 'legale iudicium' of Charles the Bald's bishops when they excommunicated Baldwin for carrying off Charles' daughter Judith and marrying her, willingly or not. ${ }^{34}$ Our French translator rendered the phrase 'leal jugement'. 'Leal' normally meant 'loyal', but a number of texts repeat the French translator's 'leal jugement', meaning 'legal judgment'. ${ }^{35}$ These texts, however, gives us no evidence

34 Janet L. Nelson, Charles the Bald (Medieval World; London 1992) 203. See also Carpenter, Magna Carta 250-253 on the European usage of judgment by peers; also Walter Ullmann, Principles of Government and Politics in the Middle Ages (London 1961) 162-163.

${ }^{35}$ I am thankful that Jennifer Jahner provided me with more information about the use of 'leal' in Anglo-Norman texts: 'Leal has a wide semantic range. Like continental French, it carries a primary meaning of 'loyal', but it also has closely affiliated secondary meanings of 'true, 'law-abiding', and 'legal'. In the romance traditions (cf. Chrétien de Troyes, Boeve de Hamptoun, Tristan), it denotes a knight of exemplary trustworthiness, and this sense seems to carry over to (or borrow from) the judicial realm, where a 'leal hume' is an oathhelper or a faithful witness. The most salient example comes from the Leis 
what a 'legal judgment' was. If we turn to literature, we do find the term used in poems composed about Aymeri of Narbonne, ${ }^{36}$ William Marshal, ${ }^{37}$ and the old trickster Reynard the Fox. ${ }^{38}$ These poems were all written in the twelfth or early thirteenth centuries. Although the texts attest that the French translator was not mechanically translating 'legale iudicium', they do not shed light on what a 'legale iudicium' or 'leal jugement' might have been at the time of Magna Carta. It does show that the translator knew that the drafters of Magna Carta translated 'leal jugement' into Latin. In other words, the terminology is taken from secular trial practices and modes of proof.

What modes of proof did the barons demand the right to have ${ }^{39}$ A trial by their peers. But what were they rejecting?

Willelme (early to mid-twelfth century), caps. 14-16 (see Felix Liebermann, Die Gesetze der Angelsachsen, 1: Text und Übersetzung (Halle an der Saale 1903) 502-503). In c.15.1, the writer refers to 'leals humes' as oath-helpers or witnesses during ordeals. The translator of the Latin version, the Leges Willelmi, renders this phrase 'legales homines'. It seems that this notion of 'leal' can slide relatively easily from describing the man capable of rendering testimony to the act of peer judgment'. See the entries in the online AngloNorman Dictionary at http://www.anglo-norman.net/.

36 Lines 2584-2586: 'S'or n'en fet Charles le los de ses amis Et le leal jugement de Paris, Ja des vasaux n'en estordra uns vis', Les Narbonnais: Chanson de geste, ed. Hermann Suchier, Les Narbonnais: Chanson de Geste (2 vols. Paris 1898) 1.97.

${ }^{37}$ Lines 13084-13087: 'Quer unques ne fui desleials, Quer cil malveisement s'escuse Qui leal jugement refuse. Isi avint la Mar'. L'histoire de Guillaume le maréchal, comte de Striguil et de Pembroke, ed. Paul Meyer (2 vols. Paris 1894) 2.107. The translation of these lines 'For I was never false; the man who refuses a fair trial puts up a poor defence of his case', is not satisfactory, e.g. History of William Marshall: Text and Translation, trans. A.J. Holden (3 vols; Occasional Publications 4 and 5; London 2002-2006) 2.155.

${ }^{38}$ Lines 1233-1238: 'Sire, fet Renart, entendez. Jugement de moi entendez. $\mathrm{Au}$ jugement me contendrai Et vostre merci atandrai. Onques ne fu nul homme ne Sanz leal jugement mene', Le roman des Renart: Les branches additionellés, ed. Ernest Martin, (Vol. 2; Strasbourg: K.J. Trübner, 1885) 230. 39 I do not find H. Summerson's analysis of the modes of proof in c.39 convincing: H. Summerson, 'The 1215 Magna Carta: Clause 39, Academic commentary', The Magna Carta Project:

[http://magnacarta.cmp.uea.ac.uk/read/magna_carta_1215/Clause_39?com=a 
The answer to that question might come from a rather surprising source: the ius proprium of the privileges of the twelfth-century emperors. These imperial privileges offer evidence that the issues that brought the barons and King John to Runnymede had resonated widely in Europe during the twelfth century. A standard, boiler plate clause was inserted into imperial privileges that granted the recipients the right to vindicate their rights either by an ordeal or by a 'legale iudicium'. Emperor Conrad II (1027-1039) granted Bishop Hiltulfus and his successors imperial protection of ecclesiastical property in $1037:^{40}$

We grant to Bishop Hiltulfus that advocates which he would have selected . . . that no public magistrate may presume to demand anything from them, so that they may more diligently pursue the legal problems of the church either through the ordeal or through 'legale iudicium'.

Privileges from emperors Henry III, Henry IV, and Frederick I Barbarossa repeated the same clauses word for word in their privileges. $^{41}$ This clause was repeated in imperial privileges for over a century. Could the meaning and the terminology of 'legale iudicium' have crossed the Channel? I do not think it impossible, even if I cannot give a source. However, the

ca accessed 15 August 2015]: 'But the presentation of judgment and law as alternatives, which to present-day eyes appears to be making a distinction between verdict and sentence, is arguably more apparent than real. The text is in fact speaking of judgment rather than proof, but the two formed inseparable parts of a single process, and Clause 39 must have been concerned with both'.

40 Conradi II. Diplomata (MGH, DD 4; Hannover 1909; reprinted Munich: 1980) p. 322, line 7-11: 'Concedimus autem eidem Hiltulfo episcopo advocatos quoscumque elegerit tam de suis quam de alienis liberis hominibus, qui eiusdem rerum utilitates episcopi exerceant, ita ut ab omni rei public• functione sint absoluti, nil ab eis quisquam publicus minister exigere presumat, ut securius ac diligentius causas ipsius • cclesi $\bullet$ perficere possint sive per pugnam sive per legale Iudicium;' noted by Ullmann, Principles 162163. Herwig Wolfram, Konrad II, 990-1039: Kaiser drei Reiche (Munich 2000; English translation, University Park 2010) 129.

${ }^{41}$ Die Urkunden Heinrichs III. 1039-1047, H. Bresslau (MGH, Die Urkunden der deutschen Könige und Kaiser 5.1; Berlin 1926) 167 lines 10-14; Diplomata Heinrici IV, ed. D. von Gladiss (MGH, DD 6.2; Weimar 1959) 566 line 20-24; Die Urkunden Friderici I. 1158-1167, ed. Heinrich Appelt MGH, DD 10.2; Hannover 1979) 127 line 46-128 lines 1-3. 
terminology is widespread and did cross the channel, as we have seen, in literary texts. What did the listeners understand by 'leal jugement' when they heard the story of Reynard the Fox? I would argue that the phrase did not conjure up an image of the ordeal.

There can be no question a 'legale iudicium' was considered an alternative to the ordeal in the imperial privileges. What mode of proof might a 'legale iudicium' be? Henry III's privilege stated that any case impinging upon the rights of the privilege could be settled only in his palace but gave no details about the procedure that should be used. ${ }^{42}$ One clue might be in a privilege of 997 in which Emperor Otto III had stipulated that an ordeal could not be used to settle a dispute about the rights of an abbey but rather could be decided by oaths of 'two or three men'. 43

Can we conclude that in chapter 39 the English barons petitioned King John to be judged by a mode of proof that was not an ordeal? If they did, does chapter 39 preclude the ordeal? The final clause 'o par la lei de la terre (vel per legem terre)' does not permit a definitive answer. ${ }^{44}$ The 'lex terrae' could mean the ordeal. Holt points out the French translator interpreted 'vel' as 'or' not 'and', a grammatical dispute of long-standing

${ }^{42}$ Die Urkunden Heinrichs III. 167: 'Statuimus ut ante cuiuslibet potestatem nullatenus finiatur nisi in palacio nostro', preceded the boiler plate quoted in n. 25 above.

43 Die Urkunden Otto des III. ed. Theodor Sickel (MGH, DD 2; Hannover: Hahnsche Buchhandlung, 1893) 655 lines 15-20e: 'Si autem quod sepissime contingere non dubium est evenerit, ut ex rebus abbatie contentio incrementa ceperit super quibus vero cartarum auctoritas igne aut aliqua negligentie occasione consumpta in presentiarum ostendi nequiverit, convessive largimur ut licitum sit predicte abbatie nostra auctoritate ut non duello aut aliquo defensionis iuditio sed solummodo duorum vel trium hominum iuramento finiatur'. cf. Hermann Nottarp, Gottesurteilstudien (Bamberger Abhandlungen und Forschungen 2; Munich, Im Kösel Verlag, 1956) 140; See Dominique Barthélemy, 'Les ordalies de l'an mil', La justice en l'an mil (Collection Histoire de la Justice 15; Paris: Association Française pour l'Histoire de la Justice, 2003) 81-92.

${ }^{44}$ Helmholz, 'Magna Carta' 356-357. 
among scholars. ${ }^{45}$ The translator's choice is weighty if not conclusive evidence to the syntax of 'vel'. The meaning of 'lex terrae' will probably never be adequately explained, especially in the context of chapter 39 , where the phrase might have meant the ordeal was an alternative mode of proof. In any case I do not think 'lex terrae' could mean judgment. ${ }^{46}$

The most intriguing evidence is at the end of the charter in chapters 52 and 57, where the formula 'senz leal judgement de ses pers (sine legali iudicio parium suorum)' is stipulated for disputes over property and rights but an alternative of 'per legem terre' is not given. Holt assumes that the French translator made a mistake in chapter 52 when he wrote 'real jugement' instead of 'leal jugement'. ${ }^{47}$ Holt made no comment about the variant. It is a simple mistake if we assume the translator worked mechanically. As we have seen, he did not. That the translator meant to write royal judgment is certainly not out of the question and has implications for our questions about procedure. Perhaps we should think about 'real jugement' a bit more. Royal judgment would certainly not be an ordeal. In the end, however, we are left with uncertainty whether the barons had misgivings about the ordeal as a mode of proof. If they did, the issue was joined a few months after Runnymede. In November 1215 the Fourth Lateran Council under Pope Innocent III definitively forbade clerics from participating in the ordeal in canon 18, Sententiam sanguinis. Chapter 39 applied to John's kingdom; Lateran canon 18 to every person in Christendom.

Richard Helmholz has written that chapter 40 is also 'very hard to understand'. ${ }^{48}$ He points out that if the text is taken literally it does not make sense in the context of English law. In England and elsewhere taking a case to court was expensive. He argues that if one places the ideas of chapter 40 in the context of

45 Holt, 'French Vernacular Magna Carta' 350. For the controversies surrounding chapter 39, see Holt, Magna Carta 226-228 ( $3^{\text {rd }}$ ed. 2015) 276278.

${ }^{46}$ See Summerson, n.20 above. Cf. Baldwin, 'Master Stephen Langton' 833.

${ }^{47}$ Holt, 'French Vernacular Magna Carta' 361.

${ }^{48}$ Helmholz, 'Magna Carta' 340-342. 
the Ius commune, the chapter is in concord with the jurisprudence of the time. There are English legal historians who have criticized Helmholz' conclusions about the Ius commune and Magna Carta, but I think they have not understood his primary point. ${ }^{49}$ Helmholz has not argued that some of the provisions of Magna Carta were taken directly from the Ius commune nor that they might not have been buttressed by the legal thought and norms of prior English law. Rather, he argued that ideas and concepts of various chapters were very much part of European jurisprudence, that is the Ius commune, at the time the charter was drafted. In only a few cases, as has been noted many times, did the drafters of Magna Carta incorporate the vocabulary of the Ius commune into the charter. No one disputes the fact that the charter incorporated canon law, and its language (e.g. 'libertas ecclesiae') which was a key part of the Ius commune. Consequently, we must not assume that the learned men who helped the barons draft Magna Carta left their learning aside as the charter was composed. The language that the drafters used is a clue to their sources but so are their ideas and concepts. That is the point Helmholz wished to make. ${ }^{50}$

Chapter 40 of Magna Carta reads:

$<40>$ A nulli ne vendrons, a nullui n'escondirons, ne ne porloignerons dreit ne justice (Nulli vendemus, nulli negabimus aut differemus rectum aut iusticiam). To no one will we sell, to no one will we deny or delay right or justice.

\footnotetext{
49 John Hudson, 'Magna Carta, the Ius commune, and English Common Law', Magna Carta and the England of King John, ed. Janet S. Loengard (Woodbridge 2010) 97-119. For an even more forceful argument, which I will touch upon below, see Thomas J. McSweeney, 'Magna Carta, Civil Law, and Canon Law', Magna Carta and the Rule of Law, edd. Daniel B. Magraw, A. Martinez, and R. Brownell (Chicago 2014) 281-309. David Carpenter has been open to see the influence of the Ius commune, e.g. David Carpenter, Magna Carta, with a new Commentary (London 2015) 262.

${ }^{50}$ Richard Helmholz made that point in an email to me: ' $<$ it was a $>$ common the habit was among English lawyers of using a different word for what was clearly a borrowing from the ius commune. It is something of a leit-motif in English legal history. E.g., novel disseisin for the possessory interdicts, slander for defamation'.
} 
As Helmholz could not, I cannot solve the larger problems connected with the difficulty of understanding chapter 40 . I shall concentrate on one word, 'rectum' that the French translator rendered as 'dreit'. If one had asked any translator to render 'dreit' back into Latin in another text, he would have undoubtedly have written 'ius'. No jurist of the Ius commune would have used 'rectum' in the way it is used in Magna Carta. They used the word to describe what was proper or correct, i.e. 'rectus ordo', 'rectum ius', 'rectum iudicium', or as an adverb meaning 'properly' or 'correctly'. As we have seen in chapter 38 with the word 'fidelis', the French translator knew that the correct word should be 'ius', which would be 'dreit' in French. 'Ius' and 'iustitia' were found together in ancient and medieval Roman law and in the Ius commune until the end of its sway. It would hardly be an exaggeration to say that the terms were inseparable in the thought of medieval jurists. The first title of book one in both Justinian's Institutes and his Digest begin 'De iustitia et iure'. ${ }^{51}$ Every person who had ever had the slightest brush with the Ius commune knew the famous maxim in the Digest, 'Justice is the constant and unbending will to render everyone his right (Iustitia est constans et perpetua voluntas ius suum cuique tribuendi', Dig. 1.2.10)'. The French translator knew it too.

To be clear, I am not arguing that the French translator took the language of 'ius et iustitia' directly from Justinian's Digest. Helmholz makes the point that if we look at Magna Carta from a European perspective we find that the same issues appear in continental law, both in the local legal systems - the 'iura propria' in the language of the jurists - and in the Ius commune. The influences and the borrowings may be direct or indirect - it is often difficult to determine in the age before Bracton - but they are there. A few years ago I tried to make the same point with Magna Carta's chapter 9. ${ }^{52}$ This is how the French translator handled the rather complicated text:

${ }^{51}$ Instit. 1.1 and Dig. 1.1; cf. Dig. 47.9.10.

52 Pennington, 'The Ius commune, Suretyship, and Magna carta', RIDC 11 (2000) 255-274. 
$<9>$ Ne nos ne nostre bailli ne seiseron terre ne rente del dettor por aucune dette, tandis com sis chatels soffisent a paier la dette, ne si plege ne seront destroit, tant dis come le chevetaigne dettor soffira a la dette paier. Et se le chevetaigne detor n'a de quei paier sa dette, respoigne li plege de la dette; e s'il volent, aient les terres e les rentes del dettor jusqu'il aient restorement de la dette qu'il ont devant paiee por lui, se le chevetaigne detor ne monstre qu'il en est quite vers cels pleges (Nec nos nec ballivi nostri seisiemus terram aliquam nec redditum pro debito aliquo, quamdiu catalla debitoris sufficiunt ad debitum reddendum; nec plegii ipsius debitoris distringantur quamdiu ipse capitalis debitor sufficit ad solucionem debiti; et si capitalis debitor defecerit in solucione debiti, non habens unde solvat, plegii respondeant de debito; et, si voluerint, habeant terras et redditus debitoris, donec sit eis satisfactum de debito quod ante pro eo solverint, nisi capitalis debitor monstraverit se esse quietum inde versus eosdem plegios). Neither we nor our bailiffs shall seize any land or rent for any debt, so long as the chattels of the debtor are sufficient to repay the debt; nor shall the sureties of the debtor be distained so long as the principal debtor is able to satisfy the debt; and if the principal debtor shall fail to pay the debt, having nothing with which to pay it, then the sureties shall answer for the debt; and let them have the lands and rents of the debtor, if they desire them, until they are indemnified for the debt which they have paid for him, unless the principal debtor can show that he is discharged of it as against the said sureties.

'Debitor' reflects the language of the Ius commune. Linguistically, it is a puzzle why the drafters used 'plegius' and not the technical term 'fideiussor'. Maybe the puzzle is not that difficult to solve. English legal documents before 1215 always used the term 'plegius' rather than 'fideiussor'. David Trotter has recently given us illustrated examples of the practice. ${ }^{53}$ Magna Carta was written for the English not for Europe. The French translator did give us one very interesting piece of evidence in chapter 40. The text of Magna Carta specifies that the debtor was the 'capitalis debitor'. This wording is intriguing. In the Ius commune the adjective 'capitalis' was used in criminal law to describe a deadly or hostile enemy or very serious

${ }^{53}$ David Trotter, ' 'Stuffed Latin': Vernacular Evidence in Latin Documents', Language and Culture in Medieval Britain: The French of England, c.11001500, ed. Jocelyn Wogan-Browne, Maryanne Kowaleski et al. (York 2013) $153-163$ at $158-159$ 
crimes. $^{54}$ It never meant 'principal', as it was used in Magna Carta. When confronted with 'capitalis debitor' in Magna Carta chapter 40, the French translator made a revealing change that may again indicate that he knew the jurisprudence of the Ius commune better than the drafters of the Latin charter. He understood that he could not use a French version of 'capitalis' if he were to accurately convey the meaning of the phrase. Therefore he translated 'capitalis debitor' as 'chevetaigne $\operatorname{det}(\mathrm{t})$ or'. 'Chevetaigne' meant 'chief', 'lord', or 'principal in medieval French'.55 In the thirteenth century, 'Bracton' employed 'capitalis' both ways. He used the term most frequently to describe a principal feudal lord, court, residence, or justiciar and less often to define a serious crime, 'felonia' and 'crimen'.56

Helmholz made two points about this chapter. First, this chapter was not included in the reissue of Magna Carta in 1225. We have no way to know if it was enforced between 1215 and 1225. Second, ancient Roman law permitted creditors to hold sureties responsible if the principal debtor became insolvent. A Novella of Justinian changed the norm to that adopted by Magna Carta. The debtor must be insolvent before the sureties could be sued for the principal's debt. ${ }^{57}$

Helmholz noted that the language of chapter nine showed no trace of Justinian's Novella. The argument that he, quoting McKechnie, put forward was, since there was no precedent in English law for the rule, protecting sureties 'found favour in

54 'Capitalis' was attached to 'inimicitia', 'crimen', 'iudicium', 'causa', 'fraus', and 'delictum;' cf. Justinian's Institutes 1.25.11, 2.20.31, 3.3.11, and 4.18.2.

${ }^{55}$ For the use of the word in medieval French, see Paul-Friedrich Bernitt, Lat. caput und *capum nebst inren Wortsippen im Französischen: Ein Beitrag zur französischen bezw. romanischen Wortgeschichte (Kiel 1905) 27-31, 37, 4142, 161-164.

56 Bracton attached 'capitalis' meaning principal several hundred times to 'dominus', and also to 'mesuagium (residence)', 'felonia', 'crimen', 'placitum', 'manerium', 'iustitiarius', and 'curia'.

${ }^{57}$ Novella 4.3.1; Helmholz, 'Magna Carta’ 319. 
most systems of jurisprudence'. ${ }^{58}$ I extended Helmholz' analysis and demonstrated that this equitable solution to the relationship between a principal debtor and his sureties became generally accepted in the Ius commune and in the various European 'iura propria'. 59

Thomas McSweeney has recently taken up the problems of chapter nine. ${ }^{60}$ He offered this translation of the main text of Justinian's Novella: ${ }^{61}$

If anyone shall have loaned money and accepted a fideiussor, a mandator, or a sponsor, he should not first proceed against the mandator or fideiussor, or sponsor, and he should not molest the intercessors of the debtor as a negligent person, but he should come first to him who took the money and contracted the debt.

The translation has a flaw. 'He should not molest the intercessors of the debtor as a negligent person' does not make sense in English and betrays the Latin. It should be 'and the fault of the debtor may not be injurious to the sureties'. 'Intercessor' is a general word in Roman law that encompasses the various types of sureties. Sweeney assumes that Helmholz thinks the drafters of Magna Carta would have taken their ideas directly from Justinian's Novella. That assumption is extremely unlikely. First, Helmholz did not assert that. He said only that the rule in Justinian's Novella became a norm in the Ius commune. Second, the text of the Novella circulated in medieval guise as a part of the Authenticum, but the Authenticum did not circulate widely. It is very unlikely that the drafters of Magna Carta would have access to a copy of the Authenticum. ${ }^{62}$ If he had written about the possibility of transmission, which he did not, Helmholz

\footnotetext{
58 Ibid.

59 Pennington, 'The Ius commune, Suretyship, and Magna carta', RIDC 11 (2000) 255-274.

${ }^{60}$ McSweeny, 'Magna Carta' 287-291.

61 Ibid. 288: Nov. 4.1.1 ' $\mathrm{Si}$ quis igitur crediderit et fideiussorem aut mandatorem aut sponsorem acceperit, is non primum mox adversus mandatorem aut fideiussorem aut sponsorem accedat, neque neglegens debitoris intercessoribus molestus sit, sed veniat primum ad eum, qui aurum accepit debitumque contraxit'.

${ }^{62}$ See Hermann Lange, Römisches Recht im Mittelalter, 1: Die Glossatoren (München 1997) 82-85.
} 
would have argued that the drafters of Magna Carta took the norm from the summaries of Novellae that were found in the margins of twelfth-century manuscripts of Justinian's Codex. These texts were attributed to Irnerius but were added to the Codex by many other jurists during the twelfth and thirteenth centuries. They were called 'constitutiones novae' or 'authenticae' by the medieval jurists. ${ }^{63}$ Their purpose was to update the texts in the Codex. If we want to speculate about how the norm contained in the Novella entered Magna Carta, we have to examine the margins of the numerous Codex manuscripts that circulated widely in England that was attached to the short and cryptic constitution of the Emperor Antoninus of 213 A.D.: ${ }^{64}$

Iure nostro est potestas creditori relicto reo eligendi fideiussores, nisi inter contrahentes aliud placitum doceatur. By our authority the power is given to the creditor of choosing sureties if he has been abandoned by the debtor, unless the contract among the parties stipulates otherwise.

This was the norm in ancient Roman law. The medieval teachers of Roman law, possibly Irnerius, summarized Justinian's legislation and placed this text next to Antoninus' constitution. ${ }^{65}$

Presente tamen utroque non permittitur intercessorem convenire priusquam reus inventus est minus idoneus in totum sive in partem. Absente autem reo presens intercessor iure quidem convenitur; ipso tamen desiderante iudex definiet tempus intra quod deducat reum primo conveniendum, ipso in subsidium reservando. Nam transacto tempore compellitur intercessor satisfacere, cessis sibi a creditore actionibus, absque distinctione contractus sive intercessionis. If both the debtor and the sureties are present the creditor may not summon the sureties before the debtor is found to be less worthy (i.e. failed in his fiduciary responsibilities) totally or partially. If, however, the debtor is absent, a surety who is present can, indeed, be convened. Nevertheless, if the surety asks, the judge will set a time within which the debtor may be convened first, with duty of the surety being held in reserve. If that time period has passed, the surety is compelled to satisfy the debt without reference to contract or to a

\footnotetext{
${ }^{63}$ Pennington, 'The Beginning of Roman Law Jurisprudence and Teaching in the Twelfth Century: The Authenticae', RIDC 22 (2012) 35-53.

${ }^{64}$ Cod. 8.40(41).5.

${ }^{65}$ Stuttgart, Landesbibliothek 71, fol. 162rb, Vienna, ÖNB lat. 2267, fol. 187r, and Paris, BNF lat. 1691, fol. 185r; every twelfth-century Codex I have seen has this authentica in the margin.
} 
veto, the creditors' court actions having been exhausted against the debtor.

This is the text that the drafters of Magna Carta would have had in mind if they were borrowing directly from Roman law. If one compares the authentica Presente to chapter nine, it is clear that the contents of the texts in the two documents are much more closely related to each other than the original text of the Novella in the Authenticum.

\begin{tabular}{|c|c|}
\hline $\begin{array}{l}\text { Authentica Presente } \\
\text { If both the debtor and the sureties are } \\
\text { present the creditor may not summon } \\
\text { the sureties before the debtor is found } \\
\text { to be less worthy (i.e. failed in his } \\
\text { fiduciary responsibilities) totally or } \\
\text { partially. If, however, the debtor is } \\
\text { absent, a surety who is present can, } \\
\text { indeed, be convened. Nevertheless, if } \\
\text { the surety asks, the judge may set a } \\
\text { time within which the debtor may be } \\
\text { convened first, with the surety being } \\
\text { held in reserve. If that time period } \\
\text { has passed, the surety is compelled to } \\
\text { satisfy the debt without reference to } \\
\text { contract or to a veto, the creditors' } \\
\text { court actions having been exhausted } \\
\text { against the debtor. }\end{array}$ & $\begin{array}{l}\text { Magna Carta c. } 9 \\
\text { Neither we nor our bailiffs shall seize } \\
\text { any land or rent for any debt, so long } \\
\text { as the chattels of the debtor are } \\
\text { sufficient to repay the debt; nor shall } \\
\text { the sureties of the debtor be distained } \\
\text { so long as the principal debtor is able } \\
\text { to satisfy the debt; and if the principal } \\
\text { debtor shall fail to pay the debt, } \\
\text { having nothing with which to pay it, } \\
\text { then the sureties shall answer for the } \\
\text { debt; and let them have the lands and } \\
\text { rents of the debtor, if they desire } \\
\text { them, until they are indemnified for } \\
\text { the debt which they have paid for } \\
\text { him, unless the principal debtor can } \\
\text { show that he is discharged of it as } \\
\text { against the said sureties. }\end{array}$ \\
\hline
\end{tabular}

I am not arguing that we can be certain the authentica Presente was a source for the drafters of chapter nine. I would argue that we cannot preclude the possibility. ${ }^{66}$ However, one may justi-

66 McSweeney, 'Magna Carta' 288-291, when comparing chapter 9 to Justinian's legislation asserts 'The format is markedly different'. His points about the differences cannot be sustained when comparing chapter 9 to Presente. It is particularly difficult to understand the point of his comparison of chapter 9 with Bracton and his concluding remark on p. 191 that 
fiably wonder whether any of the drafters looked at an intimidating copy of a glossed manuscript of Justinian's Codex. There were other avenues to the text, because Presente circulated in England and Northern France through other sources. The most probable was through Vacarius' Liber pauperum, in which Presente was added to the margin of the Worchester Cathedral Library manuscript. ${ }^{67}$ These summaries and adaptations of Justinian's legislation were major sources of law during the twelfth century, and their inclusion in Liber pauperum underlines their significance. 155 other 'authenticae' were also included in the manuscripts of the Liber pauperum. ${ }^{68}$ They even circulated separately from the Codex. Perhaps a revealing connection of Rouen to the Ius commune in Norman circles is the collection of 'authenticae' that included Presente in a Parisian manuscript. ${ }^{69}$ These texts were considered important guides to the twelfthcentury norms on many different points of private law. Franck Roumy has conjectured that the collection of 'authenticae' was put together for Normandy by the entourage of the learned Norman archbishop of Rouen, and former bishop of Lincoln, Gautier de Coutances between 1185 and 1207, who had been acting English justiciar until 1193 when Hubert Walter was

$<$ Bracton's text $>$ demonstrates what Magna Carta could have looked like had it been written by the 'ius commune's true believers'. More on that point at the end of this essay.

${ }^{67}$ The Liber Pauperum of Vacarius, ed. Francis de Zulueta (Selden Society 44; London 1927) 271. David Carpenter assumes that Vacarius was used and read in England, see Carpenter, Magna Carta 267. He also assumes that 'The tendency of legal teaching in England . . . was to play down the absolutist elements in Roman law'. Although scholars still assert otherwise, the jurists of the Ius commune did not embrace the absolutism of texts in Roman law that would have supported it, e.g. the classic study of Brian Tierney, 'The Prince is Not Bound by the Law: Accursius and the Origins of the Modern State', Comparative Studies in Society and History 5 (1963) 378-400 and my The Prince and the Law 1200-1600: Sovereignty and Rights in the Western Legal Tradition (Berkeley-Los Angeles: University of California Press, 1993) 30-37 and passim.

${ }^{68}$ Ibid. lvii-lxvii. On Vacarius and his importance in England, see Jason Taliadoros, Law and Theology in Twelfth-Century England: The Works of Master Vacarius: (1115/20-c.1200) (Disputatio, 10. Turnhout 2006).

${ }^{69}$ Paris, BNF lat. 3922A, fol.209rb-fol. 210ra. 
appointed justiciar. ${ }^{70}$ This collection is one more avenue down which Presente could have come to the attention of those who drafted Magna Carta.

Comparing the French translator's work to the texts of the chapters where the drafters of Magna Carta used the language of the Ius commune yields interesting and, as we have seen, contradictory results. In chapter one, at the very beginning of the charter, the English church was granted 'her full rights and her unimpaired (or uninjured) liberties (iura sua integra et libertates suas illesas)'. These rights included 'freedom of election (libertas electionum)'. At the end of the chapter John promised that 'he granted to all free men of our kingdom, on behalf of us and our heirs, in perpetuity, all the liberties below (Concessimus etiam omnibus liberis hominibus regni nostri, pro nobis et heredibus nostris in perpetuum, omnes libertates subscriptas)'. The French translator did not have a Latin cognate in French to translate 'libertas'. 'Liberté' entered French only in the fourteenth century; it entered English about the same time. ${ }^{71}$ The proof of that generalization is the work of a gifted linguist who translated Gratian's Decretum into French at the end of the twelfth century. Gratian had included many texts including the word 'libertas'. The French translator of Gratian confronted the same problems as the translator of Magna Carta, but he never used 'liberté' or any of its cognates. In legal Latin, 'libertas' meant a right but also meant freedom. Although 'libertas' could mean 'ius' in certain contexts in the Ius commune, there was a significant difference between 'ius' and 'libertas' in their usual usage. A 'ius' was a right to act justly and legally, while a 'libertas' was freedom that was granted by a privilege, claim, or

${ }^{70}$ For other collections of 'authenticae' that circulated independently, see Franck Roumy, 'Une collection inédite d'authenticae compose en Normandie à fin du XII ${ }^{\mathrm{e}}$ siècle', Novellae constitutiones: L'ultima legislazione di Giustiniano tra Oriente e Occidente, da Triboniano a Savigny: Atti del Convegno Internazionale, Teramo, 30-31 ottobre 2009, edd. Luca Loschiavo, Giovanna Mancini, Cristina Vano (Università degli Studi di Teramo, Collana della Facoltà di Giurisprudenza 20; Napoli 2011) 155-204, Gautier and Presente at 182 and 194.

${ }^{71}$ Chaucer, Canterbury Tales, Manciple's Tale, line 174. 
custom. Gratian had texts in which one had to distinguish between a right and freedom. ${ }^{72}$ Two of Gratian's most famous texts in which freedom would be the correct translation were Isidore of Seville's 'omnium una libertas' and the other was a text of Pope Urban II that quoted 2 Corinthians 3:17, ' ubi Spiritus Dei, ibi libertas'. The Gratian translator translated the first 'et que tuit soient franc', and the second 'ou il Esperiz Damedieu est, ilec est franchise'. ${ }^{73}$ However, when Gratian concluded 'His omnibus auctoritatibus laici excluduntur ab electione sacerdotum, atque iniunigitur eis necessitas obediendi, non libertas imperandi' the translator rendered the last clause 'et non pas franchise de commander'. ${ }^{74}$ The translation does convey the correct meaning, but without the nuance that 'liberté' would have provided him.

The translator of Magna Carta had to deal with 'libertas' twelve times. For the rights of the English churches in chapter one he wrote: 'seront franches, e ainet lor dreitures franches e enterines e plenieres (they shall be free and have their free rights, entire and full)'. He translated 'ius' as 'dreit', as he had in c.40. However, instead of acknowledging John's promise to leave the liberties, that is rights, of the English church uninjured, the translator opted to write only that the rights would remain entire and full. His formulation for free ecclesiastical elections was a challenge. For 'libertas electionum' the translator settled for 'les franchises des ellections'. The reading does not convey exactly the same meaning. 'Franchise' would be a grant of a right or the freedom to elect, but 'libertas' would be the church's right to

${ }^{72}$ See Charles Reid, Jr. Power over the Body, Equality in the Family: Rights and Domestic Relations in Medieval Canon Law (Emory University Studies in Law and Religion; Grand Rapids, Michigan-Cambridge 2004) 18-20 but especially his 'The Canonistic Contribution to the Western Rights Tradition: An Historical Inquiry', Boston College Law Review 33 (1991) 37-92 at 64-67. ${ }^{73}$ Gratiani Decretum: La traduction en ancien français du Décret de Gratien, Vol. 1: Distinctiones. Vol. 2: Causae 1-14. Vol. 3: Causae 15-29. Vol. 4: Causae 30-36 et De consecratione, ed. Leena Löfstedt (Commentationes Humanarum Litterarum, 95, 99, 105, 110; Helsinki 1992-1996) 1.5 and 3.78, Gratian, D. 1 c. 7 and C. 19 q. 2 c. 2 .

${ }^{74}$ Ibid. 1.143. 
hold an election. The difference is significant. Finally, at the end of the chapter when John granted all freemen all their liberties (omnes libertates) in the charter, the translator rendered the phrase 'totes les franchises'. As with 'libertas electionum' an explanation might be, that I put forward tentatively, a 'franchise' was a grant of a right, where a 'libertas' could be possessed independently by the person or institution. 'Libertas ecclesiae' had been a fundamental concept of ecclesiastical legal and theological thought since the pontificate of Pope Gregory VII. ${ }^{75}$ Neither Gregory nor his successors thought 'libertas ecclesiae' was a franchise from a human ruler. It was a right, 'libertas' as a 'ius'. A royalist translator who was concerned to protect royal prerogatives might very well have considered 'franchise' to be better suited for a translation of 'libertas', particularly if he were aware of the equivocal meaning of 'libertas' in the Ius commune. In any case the translator was consistent. 'Libertas' occurs twelve times in Magna Carta. The translator used 'franchise' to translate 'libertas' each time. ${ }^{76}$ However, the translator's linguistic choices were limited, and I do not think that we cannot draw any definitive conclusions from his choices. Ironically for the concord of liberties in the Anglo-Norman French Kingdom of England, 'liberté' did not yet exist in French.

Back to Rouen. Magna Carta and the IV Lateran canons occupy adjoining but separate quires at the end of the Rouen manuscript. ${ }^{77}$ The first question that confronts us is: why did these Anglo-Norman monks put these two documents together? ${ }^{78}$

\footnotetext{
75 The literature is enormous treating 'libertas ecclesiae', the essays collected in the series Studi Gregoriani per la storia della 'Libertas ecclesiae' (3 vols. Rome 1970-1989) are the best introduction to the subject.

${ }^{76}$ Chapters 1, 13, 52, 56, 59, 60, 61, 63.

${ }^{77}$ Rouen, BM lat. Y 200; see Mesmin (later MacDougall), The Leper Hospital of Saint Gilles, IV, Description of manuscript 1.162-165, IV Lateran 2.342, Magna Carta: 2.359

${ }^{78}$ I have not been able to find a connection between St. Gilles and any English institutions; cf Nicholas Vincent, 'The English Monasteries and their French Possessions', Cathedrals, Communities and Conflict in the Anglo-Norman World, ed. Paul Dalton, Charles Insley and Louis J. Wilkinson (Studies in the History of Medieval Religion 38; Woodbridge: Boydell, 2011) 221-240.
} 
The monks would have obviously wanted to have copies of the conciliar canons as soon as they were promulgated. Magna Carta began with a sturdy defense of the rights and freedoms of the English church. That would have pleased them. Paleographically, the two texts share interesting characteristics that shed some light on their origins. Both texts were written in professional scriptoria and were meant to be more than fair copies whose use would be temporary. The proof of that statement is that in both texts the initial letter of each canon/chapter was left blank, with space for an appropriate colored initial. In both cases none were provided. The reason was probably simple. The leper hospital did not have a scriptorium. However, both copies must have come from an institution with a sophisticated scriptorium. The IV Lateran canons were formatted as a typical legal text with two columns. ${ }^{79}$ The text of the IV Lateran canons is in a Northern French book hand, while Magna Carta is written by a typical chancery hand of the early thirteenth century. A striking characteristic of the Magna Carta's vernacular scribe is that he employed very few abbreviations. Minimizing the number of abbreviations would have made the document easier to read for its intended audience. $^{80}$ It would also support the assumption that many copies of the French Magna Carta were sent to all the recipients of the Latin text. We have only the Rouen text, but I think it is improbable that a text of its quality, both the French and the written text, would have been unique. If it were not unique, it must have been duplicated many times. Only the number of surviving copies is unique: Rouen.

\footnotetext{
79 The Rouen manuscript omitted two canons from its text, c.56 that dealt with tithes and c.71 in which Innocent called for a new crusade. C.71 is omitted in another manuscript and shortened in 4 others. Canons are out of place in 9 other manuscripts. It is difficult to draw any conclusions about c.56 and c.71 having been omitted.

${ }^{80}$ Albert Derolez, The Palaeography of Gothic Manuscript Books: From the Twelfth to the Early Sixteenth Century (Cambridge Studies in Palaeography and Codicology; Cambridge 2003) 187, observes 'it is not surprising that vernacular manuscripts contain only a small quantity of abbreviations'.
} 
Magna Carta and the IV Lateran canons shared a spirit of reform. Pope Innocent III sent a papal bull, Vineam domini Sabaoth, to every prelate in Christendom on April 19, 1213 in which he summoned them to attend a 'general' council in Rome during November of 2015. ${ }^{81}$ In his letter the pope had emphasized that reforms must be made in the Church and that a new crusade to the Holy Land must be launched. If we take the program in Vineam domini Sabaoth as a guide to Innocent's agenda, what he wanted in 1213 was reform of the Church, combating vices and reforming mores, stamping out of heresy settling discord and establishing peace and fostering liberty. ${ }^{82}$

Magna Carta's drafters were concerned with procedure in chapters 38-40 and so were the jurists who surrounded Innocent III. Canon 18 forbade clerics to shed blood and ordered them not to participate in ordeals. Canon eight established the rules for inquisitorial modes of proof. This new procedure offered an alternative to accusatorial procedure, which required that an accuser was essential to a criminal trial. Inquisitorial procedure granted a judge the authority to investigate wrongdoing and summon defendants to his court. ${ }^{83}$ It laid out

${ }^{81}$ The Latin text is printed and translated in Selected Letters of Pope Innocent III 144-147. See also Paul B. Pixton, The German Episcopacy and the Implementation of the Decrees of the Fourth Lateran Council, 1216-1245: Watchmen on the Tower (Studies in the History of Christian Thought, 64; Leiden-New York-Köln 1995) 1-3. A 'generale concilium' meant a papal council, see Atria A. Larson, 'Early Stages of Gratian's Decretum and the Second Lateran Council: A Reconsideration', BMCL 27 (2007) 21-56 at 2836.

82 Cheney and Semple, Selected Letters 145: 'convocemus propter . . . extirpanda vitia et plantandas virtutes, corrigendos excessus, et refomandos mores . . . sopiendas discordias et stabiliendam pacem, comprimendas oppressions et libertatem fovendam'.

${ }^{83}$ Winfried Trusen, 'Der Inquisitionsprozeß: Seine historischen Grundlagen und frühen Formen', ZRG Kan. Abt. 74 (1988) 168-230; Trusen, 'Das Verbot der Gottesurteile und der Inquisitionsprozeß: Zum Wandel des Strafverfahrens unter dem Einfluß des gelehrten Rechts im Spätmittelalter', Sozialer Wandel im Mittelalter: Wahrnehmungsformen, Erklärungsmuster, Regelungs-mechanismen, ed. Jürgen Miethke und Klaus Schreiner (Sigmaringen 1994) 235-247; Richard M. Fraher, 'IV Lateran Revolution in Criminal Procedure: The Birth of Inquisitio, the End of 
the qualities that witnesses must possess similar to Magna Carta's chapter 38. Canon 35 dealt with the rules for appeal; canon 36 forbade appeals from interlocutory decisions; canon 37 declared that defendants should not be burdened by excessive summons of witnesses more than two days distant without the agreement of both parties; one of the most important was canon 38 that stipulated all the proceedings of a trial must be recorded in writing.

'Fostering 'libertas' was on Innocent's mind when he summoned the council in 1213, but the word appears only twice in the canons. Canon 25 warned secular authorities that they should not interfere in elections contrary to 'canonica libertas'. King John granted the same rights to the English church in chapter one. The Council warned secular rulers not to legislate against the exemptions enjoyed by ecclesiastical 'libertas'. This is a good example of the equivocal meanings 'libertas' could have. One could translate 'libertas' in this canon as right, freedom, or franchise.

To return in conclusion to Charles Donahue's 'influence' of the Ius commune. I have tried to demonstrate the sometimes contradictory 'influences' of the Ius commune and continental law on Magna Carta. Those scholars who have been skeptical of Helmholz' attempts to see connections and influences have tended to understand law in the early thirteenth century as being the same Balkanized systems of positive law and jurisprudence that exists today. McSweeney is the most extreme. ${ }^{84} \mathrm{He}$ has

Ordeals, and Innocent III's Vision of Ecclesiastical Politics', Studia in honorem Eminentissimi Cardinalis Alfonsi M. Stickler, ed. Rosalio Iosepho Card. Castillo Lara (Studia et Textus Historiae Iuris Canonici 7; Rome 1992) 97-111, was his last word on the subject; he cited his earlier essays in his notes.

${ }^{84} \mathrm{~A}$ much more reasoned and balanced, if negative, discussion of the issue is found in Holt, Magna Carta ( $3^{\text {rd }}$ ed.) 15-25, by Garnett and Hudson. On p. 15 n.81 they record a conversation between Christopher R. Cheney and Holt as being 'particularly authoritative' since Cheney had not seen any connection between canon law and Magna Carta. Cheney was a brilliant historian of the Church; it does his memory no disservice to say, as he said to me more than once, that he was not a historian of medieval canonical jurisprudence. He had even less interest in the jurisprudence of medieval Roman law. 
written 'If among the drafters of Magna Carta there were any of the ius commune's true believers, they did not leave their mark' and Bracton 'demonstrates what Magna Carta could have looked like had it been written by the ius commune's true believers' ${ }^{85}$ The Ius commune was not a religion. It did not have believers. It did have teachers, students, and practitioners. Every law school of Europe taught it, and this universal, homogeneous training is how the Ius commune gained its dominance over European jurisprudence. If we had a uniform system of law schools today that had the same curriculum, taught the same books, employed the same language in their books and lectures, and used the same teaching methodology, we would have the same institutional structure that produced the Ius commune. When law students went back to practice law in their local courts, they took their academic baggage with them. None of these trained jurists thought of the law they had studied, had taught, had written about, or had practiced was in constant opposition to any other legal system. They did think the Ius commune was a source for filling lacunae and shaping legal arguments. Most pernicious, perhaps, is the modern concept prevalent in the scholarship that the Ius commune is 'learned law': bookish, cerebral, and alien to the rough and tumble of European courtrooms. ${ }^{86}$ It has been shown again and again that the practitioners in the courtroom and compilers of the iura propria took what they wanted to take from the Ius commune and left aside what they did not want or need. ${ }^{87}$

Most importantly, the Ius commune was a jurisprudence of norms, concepts, technical terms, and principles that shaped every legal system in Europe to varying degrees from the twelfth to the seventeenth century. In the twelfth century, when another Norman-French ruler, King Roger II of Sicily, ordered

\footnotetext{
${ }^{85}$ McSweeney, 'Magna Carta' 287 and 291.

86 See my rather polemical essay 'Learned Law, Droit Savant, Gelehrtes Recht: The Tyranny of a Concept', RIDC 5 (1994) 197-209 and Syracuse Journal of International Law and Commerce 20 (1994) 205-215.

87 The many works of Helmholz and Donahue have been particularly relevant for illustrating the interaction of the Ius commune and English court decisions, e.g. Richard H. Helmholz, The Ius commune in England: Four Studies (Oxford 2001).
} 
Bolognese jurists in his realm to compile a set of 'constitutions' in 1140 the jurisprudence of the Ius commune suffuses the entire work. It would have not occurred to the jurists who compiled Roger's legislation that they were betraying Sicilian or French customary legal traditions by clothing it in the language of Roman law. ${ }^{88}$ In England from the middle of the twelfth century, jurists trained in the schools of the Ius commune dominated ecclesiastical courts. ${ }^{89}$ For a brief time during the age of 'Bracton' it looked as if the Ius commune would become a part of English common law. Its influence on statutory legislation of European cities is beyond question. Manlio Bellomo characterized the relationship between the Ius commune some years ago as 'like the Ptolemaic system in which the earth lay immobile at the center of a horizontal plane while the sun in its heavens moved around it every day, illuminating and warming it'. ${ }^{90}$ Bellomo's metaphor is apt and fitting to define what Donahue meant by 'influence'. John Baldwin concluded his piece on Stephen Langton and Magna Carta with these words: 'Considered separately, these linkages may appear slight, but taken together they form a coherent picture'. ${ }^{11}$ Perhaps the picture in this essay is not completely coherent, but in honor of John's memory I use his words to conclude my essay.

The Catholic University of America.

${ }^{88}$ See my 'The Birth of the Ius commune: King Roger II's Legislation', RIDC 17 (2006) 1-40.

${ }^{89}$ The literature on this point is large; most recently see James A. Brundage, 'The Managerial Revolution in the English Church', Magna Carta and the England of King John, ed. Janet S. Loengard (Woodbridge 2010) 83-98.

${ }^{90}$ Manlio Bellomo, The Common Legal Past of Europe, 1000-1800 (Studies in Medieval and Early Modern Canon Law, 4; Washington D.C. 1995) 192.

${ }^{91}$ Baldwin († February 8, 2015), 'Master Stephen Langton' 846. 